\title{
Martin Luther King Encounters Post-racialism
}

\author{
Kimberlé Crenshaw
}

W

e've been proclaimed to be post-racial. You might have missed this declaration and the moment that we stepped out of history and into the glorious land of milk and honey. So let me take you back to the instant we crossed the finish line. Perhaps you were there, or saw it on TV, and did not realize that at that moment, at the inauguration of the first African American president of the United States, we officially became post-racial. Just in case we missed the point, the symbolism of the occasion was punctuated by repeated references to Martin Luther King, whose appearance was like that checkered flag at the finish line proclaiming that at that moment, not only had Obama arrived, but so apparently had we all. While we might forgive the excitement of that event, the thrilling way in which all Americans seemed to invest that transition with transhistorical significance, on greater reflection, years later, can we really say that we are now a post-racial society? Have we in fact arrived?

Of course, this begs the question of what exactly we mean when we say "post-racial." What work is the post in "post-racial" really doing? Does the post signal the opposite of racial, so that in fact we are claiming to live in a non-racial society? Is there a particular set of social relations that have come into being that can fairly be called non-racial? Or is it that post-racial marks a temporal moment, a finish line that we have crossed as a result of the mere passage of time? Is post-racial a provable reality in the here and now, or is it an insistent denial that race is still here? Is post-racial a mission accomplished, or merely a dream deferred? What really is post-racial?

My hunch, of course, is that you might be skeptical about the post-racial proclamation. I suppose no one would be more puzzled by this proclamation that the Dream has been achieved than the Dreamer himself, Martin Luther King. How ironic, I thought, that his image, his words, his being would be

\footnotetext{
Kimberlé Crenshaw is a professor of law at the University of California, Los Angeles, and Columbia University. Her primary teaching and scholarly interests center on race and the law; she was a founder of, and has been a leader in, Critical Race Theory as an intellectual movement. She is the executive director of the African American Policy Forum, a think tank designed to highlight the centrality of gender in racial justice discourse and illuminate patterns of institutional discrimination.
}

Kalfou, Volume 1, Issue 1 (Spring 2014). ( 2014 by the Regents of the University of California. ISSN 2151-4712 (print). ISSN 2372-0751 (online). http://dx.doi.org/10.15367/kf.vli1.8. All rights reserved. 
called forth to punctuate a claim that would be hard for him to fathom. Such is the plight of martyrs, no doubt, often forced by death to silently authorize circumstances at odds with the vision for which they gave their lives.

But what if Dr. King could speak?

What if the joyful inaugural celebration had cracked open the celestial separation between the living and the world beyond, so that Dr. King, awakened by all the trumpeting that we had arrived, could have engaged us? What might his reaction have been upon hearing the newsflash that we've reached the post-racial Promised Land? As I drifted into deeper meditation about what that conversation would have sounded like, it seemed that I started to hear a conversation unfolding in my head, bits and pieces at first, but then slowly, as if I were tuning in to some cosmic channel, it became a conversation that I could hear, and eventually visualize as clearly as if it were on $\mathrm{HBO}$.

The scene is vivid, but I cannot tell exactly where it is taking place. It is surely some place between the here and the hereafter. From the levity of the scene, it appears that an announcement has just been made that we living creatures have finally worked through all the racial drama down here. The generals of the warring sides of our racial history are laying down arms and the hardworking soldiers of the social justice movements are kicking up their feet. César Chávez and Malcolm X are laughing it up with Barry Goldwater, and Fannie Lou Hamer and Betty Friedan have taken the day off. Geronimo has invited the 4th Cavalry over for a quick celebratory bite. Robert E. Lee has just popped open a bottle of two-hundred-year-old whiskey with Ulysses S. Grant, and even Susan B. Anthony and Frederick Douglass are on speaking terms again.

Dr. King is here too, but he is pensive, perhaps not skeptical so much as curious. "Just where is post-racial, and how did we get there?" he asks Thurgood Marshall in the midst of a big bear hug and an awkwardly attempted high five. Perhaps because Dr. King's name is being so frequently invoked in the festivities below, he is just about to find himself beamed onto center stage, where he will find out for himself.

Back on Planet Earth, it's indeed a special day among the living. An unknown rule on such days is that the gazillionth person to invoke a historical figure finds himself face-to-face with him. It just so happens that the gazillionth person is a cub reporter on CNN, not someone we'd all know yet, but a familiar voice of conventional wisdom all wrapped up in a congenial and friendly package. Let's call him Barry King-yes, the youngest son of the talk show giant, Larry King. He is sitting in for his dad on MLK Day, talking to a stream of guests about how Dr. King's Dream has finally been realized.

Of course, Barry must think he's seeing things when Nancy Pelosi begins to morph into someone else, like in Michael Jackson's "Black or White" video: first into a white man, then into a Black man, then finally into MLK himself. Reporter that he is, Barry does not skip a beat-this is going to be the scoop of 
the century! Barry King is a chip off the old block: nothing is too incredible for him! Man bites dog, Palin for President, Dr. King in the flesh. Sensational news is all good news to him. So here they are, two Kings, Barry and Martin, man to man, alone in the studio while the festivities continue.

"Tell us how it feels, Martin, uh, Dr. King, to know that your Dream has come true. Must be pretty thrilling."

"Actually, I was hoping you'd tell me all about it. I've been to the mountaintop and knew that one day we would arrive. But I'm here to learn how we got there. I want you to paint a picture of it for me, please."

"Dr. King, it would be an honor. I'm not a specialist in these matters, but I can tell you what I know. Here, take a look at this. It's a computer monitor. Just think of it like a newspaper on TV. It's just going to be scrolling through some things while we talk to give you an idea of what's been going on since you, uh, left us. Just hit this button here to pause on anything that catches your attention. I think it'll give you a good idea of why we're all excited here."

Barry turns his monitor so his guest can see it. Dr. King jabs at the screen a few times, but after a puzzled glance at the keyboard, he leans in toward Barry. He really wants to hear the story, not read about it.

"Let's start with the end of my Dream, where I saw little Negro boys and girls walking hand-in-hand with little white boys and girls. Tell me about the schools, Barry. Is it like the Supreme Court finally promised, that we will reach the day of full integration when there are no Black schools, no white schools, just schools? We're in the Promised Land now, so we must not only have 'just schools,' but just schools."

"We can't really say we've got 'just schools,' or even just schools. We still have schools, Dr. King, but while they aren't segregated anymore, they're not exactly integrated either."

Dr. King frowns just a bit. This distinction is as entirely newfangled and bizarre to him as a Blackberry or an Xbox.

"Not segregated, but not integrated either? In my Dream, the children are hand-in-hand. How can this happen if they're neither segregated nor integrated?"

"Let me put it this way: it's what we call virtual integration. They're together here," Barry explains, tapping his head. "'Cause you know, we're all just Americans now, not Black, not Brown, not white, yellow, or red."

"If we're all just Americans, why are most children still attending schools in which they are the majority race? Why is it that Black school children are more segregated in 2010 than they were in 1964? And why has this plight been extended to Latino students, more than fifty-six years after the Supreme Court struck down school segregation for Latino students? What does any of this have to do with my Dream?"

"Dr. King, your Dream is realized because parents are choosing where they want their children to attend school. People choose what neighborhoods they 
live in, what schools they attend, what futures they'll have. At the end of the day, that is what you really were protesting, right? The inability of Black parents to choose their children's destiny?"

"Actually, this business about choice is what we used to hear in the '50s and '60s from white parents trying to push back the integration of schools. In fact, school districts frequently turned to freedom-of-choice plans to defeat integration. White parents wouldn't budge and the few Black parents who opted for white schools saw their jobs go out the window, their mortgages foreclosed, and their families sometimes even threatened thanks to the organized resistance of white citizens' councils. We knew then that so-called choice in an unchanged power structure was only going to produce more segregation. The Supreme Court finally struck down free-choice plans and required school boards to take affirmative steps to dismantle these dual school systems."

"You might be surprised to know that the city of Louisville was one of those school districts that took seriously their responsibility to dismantle separate school systems and to keep them that way. But now, at least a plurality on the Court believes that the use of race to diversify schools is as poisonous as using race to segregate schools. In fact, Clarence Thomas-sorry, you don't know him, long story-says there is a moral equivalence between the two."

"A moral equivalence between segregation and integration? I can't quite understand what you're saying, Barry. Are you saying that the highest court in the land, the court that declared that segregation damaged the hearts and minds of children in a way that will never be undone, the court that ruled in favor of people like poor Linda Brown, who walked past well-equipped schools in her neighborhood to go to an underfunded school cabined off for colored people, is now saying that the little white children in their modern neighborhood schools and Linda Brown across the tracks were each being harmed by segregation in the same way? That's as ridiculous as Plessy versus Ferguson, when the Supreme Court upheld segregation by saying that Negroes and whites were equally affected by segregation: Negroes could not sit in white cars and whites could not sit in Negro cars. Everyone knew that segregation wasn't symmetrical; it was meant to keep the Other down, out, and robbed of opportunity and dignity. I thought this specious argument died when Brown was decided. The Supreme Court opened the door to integration, and although it disappointed us at times, it was always clear that the goal was to eliminate segregation root and branch. How can the Supreme Court be in the way after all these years?"

"Uh, sir? Just a hint. Your people are called African Americans now. We're post-racial, so you could get in trouble using a term that is, well, out of date. A senator got in some post-racial hot water about that a few years ago-and how! But yeah, you've got the idea. Taking account of race, that's the old racialism that harms whites and nonwhites alike. Ignoring race, now that's post-racial. So Linda Brown in the Black school and the nameless white kids in the white 
school, they were all victimized by a policy that took their race into account. Post-racial means being color-blind. It doesn't matter whether the goal is to segregate or to integrate the schools in post-apartheid America; the use of race is equally off the table."

"Let me get this straight," says Dr. King, returning now to his monitor to look at statistics on segregation in schools. "We have Black schools, white schools, Latino schools. Many are poorly funded, isolated, and failing. And these schools are increasing in number. But we can't do anything to integrate these schools because we're now living in a post-racial Promised Land where race is over? How can we possibly be over race when an institution as important as the public school system remains nearly as racially segregated today as it was in the '50s?"

Barry puts his hands over his ears. "LA, LA, LA, LA, LA, LA ..."

Dr. King looks puzzled. "What's wrong with you? What are you doing?"

"Sir, I'm just trying to talk over you. It's what we do now. It's a new postracial rule. Actually there are three rules: see no race, hear no race, say no race. After all, we're post-racial."

"How would you know if we're really post-racial if you can't see, hear, or talk about race or racism?"

"That's part of the point, sir. We don't want to see, hear, or talk about it. When we don't, most folks feel pretty OK about that. In fact, in California there was an effort to eliminate the collection of all racial data. I know, those Californians do some crazy things, but a lot of folks thought it was a good idea and that it would solve a lot of racial problems. People thought that if you take away the ability to measure racial disparities, you also take away the ability to fight about them. Problem solved. Racial to post-racial in lickety-split time. Who could ask for more?"

"So the solution to racial disparities in school funding, in health care, in profiling, in early deaths, in environmental diseases, in unemployment, in land loss and property foreclosures, in family dissolution, and in homelessness is simply to stop asking, stop noticing, and stop reporting?"

"Yup, that's the ticket to post-racial, sir. And you'd probably be impressed by all the foundations and politicians that now march under your banner. It's a 'who's who' list of the old anti-Civil Rights juggernaut and their intellectual descendents. They call themselves the American Civil Rights Institute and stuff like that. You're everybody's hero now, Dr. King. Say, did you know we even have a holiday to celebrate you? Everybody thought it was a good idea. Well, in most parts of the country. There were a few exceptions."

"So the post-racial solution to the continuing legacy of racism is to ignore race altogether? This is what living the Dream means? Just ignore racial injustice and let it fester?"

"Sir, please! You can get in trouble for saying that there is still a race problem. Well, hold on a second, let me clarify that a bit. You can get in trouble for 
saying that racial problems have something to do with racism. That's called the 'politics of racial grievance' and you certainly wouldn't want to be put in that category. You'd be accused of being one of the race-mongers, or-sir, not to offend you, I know that you're a man of the cloth-sometimes you might even be called a race pimp. Now, fortunately enough, no one calls you that because, well, you died before racial justice advocacy went out of fashion. But now that you're back, you might want to stay away from anything that smacks of racial complaint. People don't like that, sir."

"Now I am profoundly confused. Advocacy is out, but you can talk about race in other ways?"

"Yeah, I can see how that's a head-scratcher. I'll give you a few examples to explain. Obama-I'll fill you in on that in a minute-ran for president in 2008. He was the first Black man to have a shot, but let's face it, you don't look at him and immediately think, American president. So he said, hey, don't be scared away because my name sounds funny, or my face doesn't look like the one on a dollar bill. Vote for me anyway, because I'm the best candidate for the job."

"And the post-racial problem with that would be?"

"Isn't it obvious? He is suggesting that race might have something to do with white voters' reluctance to vote for him. He's playing a race card, don't you see? That's against the rules. Can't do that."

"But I can't imagine how that wouldn't be true. In fact, I can't imagine that there wasn't plenty of survey evidence that suggested that color was a factor he would have to overcome in winning the hearts and minds of white voters."

"Sure, that's true. But a post-racial world is an 'as if' world. We're supposed to act as if racism doesn't matter, don't you see? And Obama broke the rule by humming a few bars from racial justice advocacy, something you might have done-respectfully, sir, back in the day-but it's inappropriate now. So he got busted for it, but you know, he managed that one well."

"Are you saying that he ran a post-racial campaign and won?"

"No, not exactly post-racial. In the mass public arena, save for a few missteps like that, and one big slip into the cow dung, he managed to steer away from too much racial mongering. Just on the QT, sir, he accepted his nomination on the fortieth anniversary of your 'I Have a Dream' speech, but he didn't quite mention you by name. But you know, we all knew who he was talking about when he said, 'that preacher', and a lot of pundits thought it probably made good sense not to be too closely tied to you."

"I am certainly not invested in being honored. I'd rather my Dream be realized, than my name be called."

"On the post-racial line, you'd be really impressed with Obama's ground campaign. He tore pages right out of your brilliant mobilizations on behalf of the common man. Although this time, the common man was the white union 
guy in Pennsylvania and Ohio, guys who never dreamed they would vote for someone like him, and to be honest, wouldn't have done so without white Americans going door-to-door, talking explicitly, honestly, and face-to-face about race and racism. It wasn't easy, and those guys learned a lot about how deep the racial polarization was in this country, especially among working men and women who were losing their jobs, their health care, their sense of self. It was hard for them to imagine that a Black guy would have a platform that was better for them than the guy who looked like their pops. But enough came over to make it possible. That's why we're celebrating post-racialism today. We overcame!"

"Help me out here. We're celebrating a notion of post-racialism at odds with what really happened? There was nothing post-racial about that hard work, and certainly nothing 'post' about the racial attitudes people encountered going door-to-door. So if we were able to accomplish that in a campaign, I don't see why this approach can't go public."

"That's because there are a couple of nuances to the post-racial rules you need to know. First, there's a real public/private distinction. We all know there are things that can be said in private about race all the time. Why, just the other day I was talking to my barber who told me the funniest joke about Obama ... uh, well, never mind. Sorry about that. Anyway, just to let you know, there's plenty of evidence that there's still racism. It's apparent in private conversations and observations all around. So that stuff is there, but that's not the country's official stance on race. The official stance is post-racial."

"So what I'm hearing is that we dream a world in public discourse that our private lives repudiate every day? If that's post-racial, then we're moving at a glacier's pace away from the past."

"It wouldn't be quite right to say that all talk of race is being pushed off the table. There is still plenty to talk about. Take candidate Obama on Father's Day, when he gave a great talk on personal responsibility and Black fathers. He told Black fathers that a lot of them were being irresponsible. That speech went over really well."

"I'm at a loss here. Talking about fatherhood and responsibility as though it were a distinctively Black problem didn't break the new post-racial rules?"

"Oh no, sir, why would it? The rule is pretty much not applied to discussions about really important problems. I mean, there are some racial things we have to talk about, wouldn't you agree? Like crime, family breakdown, and the really big issue nowadays, intellectual underdevelopment and racial achievement gaps. When we talk about why the public school system isn't doing so well because of schools with people of color in them, we've got the full house of racial discourse, from cultural deficits to motivational deficits, from entitlement to hip hop. But that's OK, no post-racial rules violated here." 
"Let me understand a few things about this racial achievement gap. I am not a social scientist, but I'm assuming that in order to highlight racial differences in this gap, all other conditions have been equalized, such as funding equity, teacher competence, school conditions, curricular relevance, and the like. I'm assuming as well that the myriad ways that social exclusion intersects and compounds inequality are accounted for as well."

"By that, sir, I believe you might be referring to intersectionality-the ways that certain forms of discrimination overlap and interlock with each other. You're quite right to inquire about it. This notion was always implicit in your work; in fact, it was the intersection of race and poverty that took you to Memphis where you were ... uh, well, yes. And you would be happy to know that our understanding of your insight has grown, first in regard to employment. There was a rather curious case that illustrated the problem, involving a group of plaintiffs who sued a car manufacturing company alleging discrimination against them as Black women. The company defended itself, pointing out that it did hire Blacks and it did hire women, so that the Black women had no claim. But, get this, the Blacks they hired were men (for floor jobs) and the women they hired where white (for front office jobs), so the Black women were still out of luck. They argued that this was compound discrimination, the interlocking effects of gender discrimination in the floor jobs, and race discrimination in the secretarial pool, but the court just dismissed that claim. See, the way this court saw it, the plaintiffs should not be able to combine two separate claims into one; that would make them a superclass, and it would give them unfair preference over everybody else. No one else can combine their claims, so they should not be able to either."

"This is just making my head spin. So these Black women-they were being discriminated against on the basis of their race and gender, so they are the only ones here that need to combine the claims so their situation can be addressed, but to give them what they need, to remove these obstacles, is special treatment?"

"Yes, sir. You see, our courts don't get intersectionality. They think that if there's race discrimination, everyone would be similarly burdened, and if there's gender discrimination, all the women would be treated the same. Here, the fact that there is discrimination within discrimination-the fact that racism and sexism intersect-well, that's just too much arithmetic to figure out. But the courts don't get race and class, or class and language, or race and disability any better than the rest of us. Few people do, sir, even though, as I think you've seen from this example, these problems are pretty pervasive."

"If they don't get intersectionality, then how can they talk about a racial achievement gap? It seems to me that is as ridiculous as telling these Black women who sued the car manufacturer that they were suffering from an employment achievement gap. First, it does not take into account the way the system is structured in a way that excludes them, particularly the overlapping practices and policies that affect different groups within it. Then, after permit- 
ting these processes of exclusion, the final insult is to lay responsibility for the consequences at their feet, telling them that they are expecting preferential treatment if they demand interventions that work for them."

"That would probably be a fair assessment, Dr. King, if there were commitments to achieving fairness and equity on all these measures. Then the failure to follow the way they intersect would obviously be a problem. But you should know that it's not just the judicial and legislative failure to see intersectionality that hamstrings education, sir. It's the fact that there are no basic and bankable guarantees for education equity. Education isn't a fundamental right, and indeed, there is no right against class discrimination. The Court saw to that in San Antonio versus Rodriguez, when it declared that the Constitution did not prohibit funding formulas that discriminated against poor and immigrant school children."

"Let me see if I can understand what you're saying about this post-racialism, what it permits us to interrogate, and what it does not. Performance disparities can be talked about as inherent characteristics of the children-whether they are cultural, cognitive, social, or other problems. But discussing the legacy of race in structuring opportunities, funding, and the internal dynamics of education itself is embargoed as post-racial? We can't talk about what's happening now?"

"I would be the first to admit that it's a bit of a contradiction. But we have pretty much decided that all this talk of race and racism is just, well, counterproductive and makes people feel kind of bad. And, if I may be so bold to say, this isn't a far cry from how your holiday is often celebrated. In fact, the very first commission on MLK Day-headed by notable Civil Rights colleagues and even your wife-recommended that the day not be used to criticize or to politicize American society, but to live the Dream of a world in which race doesn't matter. So now it's MLK Day every day! The move from race-conscious advocacy to living the Dream has been underway all along. Now that we're truly post-racial, your holiday gives us a great opportunity to congratulate ourselves on how far we've come!"

"Barry, I'm having a difficult time understanding exactly how far we've come. What I've heard so far is this: our schools are as segregated as ever before, but the good news is that no one can use race to classify students; we still have disparities that are profound along every data point we can think of, but the solution to that is to stop collecting data; we elected an African American as president, which proves we don't have to talk about race, but it took a massive talking campaign to make it so; we can talk about races performing badly, which is not race-mongering, but we can't talk about racism, because that is race-mongering. And this is all supposed to be part of my Dream?"

"In a word, yes. You were the one who encouraged people to think not in terms of skin color, but in terms of the content of their character. And that's 
what post-racialism is all about. Ignoring skin color, and paying attention to people."

"But I also said, quite clearly, that we were going to march to Washington, DC, to cash a promissory note, one that promised structural and institutional change, a note that would give all Americans an opportunity to make good on the promises of the Declaration of Independence and the Constitution. Something more was necessary than to muffle discourse about race. I called on us to do something affirmative, to dismantle the structural chains that limit the life chances of people of color, to make good on this national debt that only grows rather than lessens over time."

"You should know that there have been a few who agreed with you. Gloria Ladson-Billings also mobilizes this idea to argue against the notion of achievement gaps, and for an idea of education debt. In Bakke, Supreme Court Justice Blackmun quite clearly said, 'To get beyond racism, we must first take account of race.' But really influential people have also rejected the notion that you have to take race into account to get beyond race, or even that there is a debt to be settled. Justice Scalia, who now sits on the Supreme Court, plainly stated that there is no creditor race, there is no debtor race, there is only the human race. So post-racialism now means that we're beyond the concerns that you focused on. You know, it's been fifty years, Dr. King. And since you so brilliantly introduced the notion of the promissory note in your 'I Have a Dream' speech, maybe it might be helpful for you to think of post-racialism as a declaration of bankruptcy. It's not a temporary statement of insufficient funds that might suggest a settlement will be forthcoming. It's a note that says the debt is wiped clean, period. It's just like what ordinary people do when they can't pay their debts. You sit it out for seven years in the penalty box, and hey, you're good to go. No creditors, no debtors! You can start all over. So post-racialism is like bankruptcy. We're overburdened and there's no more social justice capital to pay that promissory note, so we're filing for post-racialism. We've filed, we've sat in the penalty box for the appropriate amount of time, and now the debts have been removed. It's time to move on."

"But time is neutral. It seems that the proponents of post-racialism think that just the ticking clock is enough, that post simply means enough time has passed."

"Clearly that's reasonable, isn't it, sir? You can look around to see the passage of time. New possibilities have emerged, not only in the White House, but elsewhere. For professionals and the middle class in particular, there's been substantial growth in their political participation over the years. Isn't that change you can believe in? Plus, any race-based plans like the ones you proposed are really unpopular among the white majority. With respect, at the end of the day, isn't that what you were really trying to get at?"

"What I am for at the end of the day is racial justice. I have always been ex- 
plicit in supporting affirmative actions, positive steps, race-conscious and otherwise, to remove the obstacles that make equal opportunity a myth rather than a reality for many of our colored citizens."

"Well your domestic Marshall Plan never really happened, Dr. King. And if it had, it would have had to be color-blind, not race-conscious. Like Chief Justice Roberts said, how are we ever going to get beyond race if we keep paying attention to it? Doesn't he have a point when he says, 'the way to stop discrimination on the basis of race is to stop discriminating on the basis of race'?"

Dr. King sighs. He appears confused and puzzled. "But this does not make sense. It's like saying that the way to get rid of asbestos-linked diseases is to stop looking for, seeing, or saying the word asbestos. It's like saying that the problem of asbestos is that we are getting sick because we are paying attention to it. So we should not look for it, nor develop tools to protect ourselves from it. If we do not see it, it will not harm us. Well, this is a fairy tale that even a kid knows is senseless. It doesn't take rocket science to figure out that you can't throw out the very tools you need to identify asbestos and hope to protect against lung cancer, the same way that you can't solve a race problem in society by not talking about racism or throwing away all the tools used to protect us from it. This is flying blind. You are destined for disaster if you are confronted with a problem that you can neither name nor correct."

"People have been debating this for some time now. On race consciousness in particular, our conservatives and liberals agree that affirmative action compromises the equal opportunity race by giving people of color a head start, but they disagree about whether doing so is defensible. Liberals, like your friend Lyndon B. Johnson, say that you can't bring a man in chains to a starting line and expect him to run the same race as someone who is unencumbered. Conservatives say that giving a head start is not the solution; it isn't fair to the runner nor to the others he's running with. They agree that with affirmative action, it is the damaged runner who crosses the line first, but they disagree about whether this is defensible or not."

"And that would be the exact problem with this post-racial argument. That liberals and conservatives disagree isn't significant; what is significant is where they agree. Here I part company with my good friend LBJ. If you listen closely, both political groups think the problem is damaged runners, while I, for one, think the problem is not damaged runners but damaged racetracks. The equal opportunity race never has been a fair and square one, from the very beginning. Race-conscious intervention wouldn't be seen as unfair or an unjustified preference if we focused not on damaged people, but on damaged institutions, damaged races, damaged lanes on the racetrack. We have to remove the effects of these obstacles and balance the preferences that are on the track, the advantages for the people on the automated people mover, people who are born to families of privilege. I mean, it may be apocryphal and I will have to stretch 
credulity to make my point, but think hypothetically about a son of privilege, one who does fairly poorly at an elite school, but who, because of his ties and social connections, earns a slot, say, at Yale University. Let's say our hypothetical son of privilege does a bit better, earns a $\mathrm{C}$ average, and then, due to the grace of wealth, wins a slot at Harvard Business School. And just to stretch the imagination one more step, let's say he goes on to create spectacular failures in the world of business, and, thanks to his name, he wins the best job in America, president of the United States. It may be hyperbole to be sure. Who can imagine that happening? But my point is, if this were to happen, no one would ever see this as the true negative consequences of preferential treatment, but that is certainly what it would be."

"I understand what you're saying, but we're getting short on time."

"Time and silence are a deadly combination. We as a society believe we are getting away from the ugly past. We cannot hear the siren song luring us toward the shoals where we will run aground on our own history. Post-racial isn't a temporal concept. It isn't an accomplishment; it isn't a place and it isn't a time. It sounds to me that it's just another way of wrapping up the challenges we face in a manner that allows us not to think about them and to silence those who do. I encountered this phenomenon during the Montgomery bus boycott. At that time the language was one of gradualism, that our day would eventually come. Many of the purveyors of this approach were my fellow ministers who called me to task for my work as an advocate. But, as I said in 1962, it is good to be maladjusted to injustice. I don't mind marching to the beat of racial justice even if I am the only person in the parade. I broke the rules of engagement that permitted racial injustice to live easily in a society that claimed brotherhood and respect; if I were here now, I would certainly refuse to deny the urgency of our rightful expectations."

Barry is thankful that his hour with Dr. King is apparently winding down, as his image is starting to fade. "Dr. King, we're really out of time now. Do you have any parting words for us?"

"It seems to me that the language of gradualism has matured into a language of arrival. Back then they told us don't rock the boat, and now they are telling you there is no boat because we've arrived. But this is a fantasy, one that we will regret if someone doesn't wake everybody up. Who history calls upon to tell its truths remains to be seen." 